\title{
Effects of Working Specification of Weft-Accelerating Apparatus on Weft Insertion for Air Jet Loom
}

\author{
Atsuji Masuda*, Kazuo Washida*, Yoshimasa Sogi** and Nobuo Ogata*** \\ *Fukui Industrial Technical Center, 910-0102, Kawaiwashizuka, Fukui, **former Micron Corp., \\ 146-0092, Ota-ku, Tokyo, ***Fukui University, 910-0017, Bunkyo, Fukui
}

\begin{abstract}
In an air jet loom, compressed air is used for the weft insertion. In order to produce the compressed air, much electric power is necessary. To reduce the energy, an accelerating apparatus of the weft yarn (PDC-system) has been developed and the efficiency of the apparatus was assessed in the previous work. It was found that the energy for the weft insertion could be reduced by using the apparatus.

For this apparatus being used in various air jet looms, the flight state of the weft yarn should be analyzed in detail. In this work, the effects of PDC working conditions on the tip velocity of weft yarn and the weft yarn tension are investigated. From the investigations, it is found that the flight state of the weft yarn is more easily controlled by using the accelerating apparatus of the weft yarn.
\end{abstract}

Key Words : Weft insertion, AJL, Weft yarn velocity, Weft yarn tension

(Received March 29, 1999) (Accepted for Publication Sept. 30, 1999)

\section{エアジェットルームよこ糸加速装置の稼動条件が \\ よこ入れ運動特性に及ぼす効果}

\section{増田 敦士*，敦田 一夫*，曽木 芳正**，小形 信男}

\section{1. 緒 言}

エァージェットルーム（AJL）は，圧縮空気を利 用してよこ入れを行うため,よこ入れ可能な緘維素 材の制限む少なく, 汎用性に優れている1). 特に, 近 年の多様化した新素材および複合素材等の糸種に対 応できるため, 高付加価値織物の製造に適してい る.しかし，AJL はよこ入れ運動のための圧縮空気 用電力消費が大きく, これが欠点となっている.こ の削減対策のひとつとして，これまであノズル形状
・おさ等の改良が行われ, 圧縮空気の利用効率向上 が行われてきた，その一方，よこ入れを機械的に補 助するよこ糸加速装置の開発も行われ ${ }^{2,3)}$ ，前報4)で はその効果を明らかにした。しかし，この装置が製 織現場において広く普及するためには，装置使用時 のよこ糸の飛走状態および装置の耐久性等を詳細に 検討する必要がある. 特に, よこ糸の飛走状態は, 織物の構造や力学特性等の織物物性および製織効率 に大きく影響を与えるため，その解明は重要であ り，さらに，よこ糸飛走状態をよこ系種に対応して

*会員，福井県工業技術センター，福井市川合然塚町，TEL. 0776-55-0664，FAX. 0776-55-0665

**会員, 元マイクロン(儌), 東京都大田区下丸子

***会員, 福井, 大学工学部, 福井市文京 3 
任意に制御できる簡易な方法が現在求められている. そこで, 本報ではよこ系加速装置を使用した場合 のよこ入れ運動特性を検討した。 その結果，よこ入 れに対する抵抗力が比較的小さい自由飛走状態が実 現できること，稼動条件の適切な設定により容易に よこ糸飛走状態を制御できることが明らかになった ので報告する.

\section{2. 実験装置および実験方法}

\section{1 製織条件}

製織実験は，前報と同様に(㑣豊田自動織機製作所 製のエァージェットルーム（JAT600）を使用して行 った．織幅と織機の駆動回転数は，それぞれ $130 \mathrm{~cm}$ および565rpm (土2rpm) である.

よこ入れにはメインノズル，タンデムノズル（よ こ糸加速装置使用時を除く), 補助ノズルおよびス トレッチノズルを使用した、メインノズルおよび補 助ノズルの空気圧は, 織機の各圧力タンクにつなが る配管に圧力計（侏岡野製作所：デジタルマノメー ター）を設置して測定し，実験時のメインノズルお よびタンデムノズル空気圧はそれぞれ $178 \mathrm{kPa}$ であ り, 補助ノズルおよびストレッチノズルの空気圧は それぞれ $192 \mathrm{kPa}$ であった。

よこ入れ条件であるノズル構成および噴射夕イミ ング，よこ糸の解放タイミングは，図 1 に示す条件 を使用した（織機各部の稼動タイミングは織機のお さ打ちを起点とし，クランク 1 回転を 360 度とした ク.ランク角を用いて表記する).

\section{2 よこ糸加速装置の稼動条件}

よこ糸加速装置 (Pinch-Roller Direct Control System，以後 PDC 装置と表記する）は，前報と同

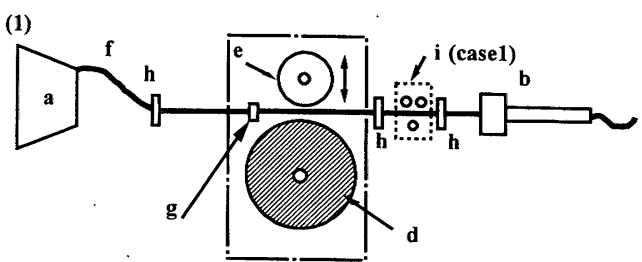

(2)

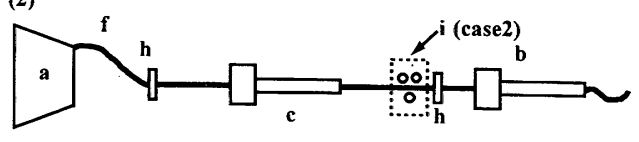

a : weft yarn feeder, b : main nozzle, c : tandem nozzle d : driving roller, $e:$ pinch roller, $f:$ weft yarn

$g$ : traverse yarn guide, $h$ : yarn guide,$i$ : tension meter

Fig. 2 Supplementary apparatus for weft insertion (PDC-system)

じあのを使用した（図 2(1); 一点鎖線で囲まれた部 分が PDC 装置である). PDC装置を設置しない場 合は, 図 2(2)の c で示されるように PDC 装置と同 じ位置にタンデムノズルを設置した。

PDC 装置の稼動条件には, 駆動ローラー回転数 とピンチローラー稼動タイミングがある. 以後, 駆 動ローラー回転数を DR 回転数, ピンチローラーが 稼動しているクランク角度範囲を $\mathrm{PR}$ 稼動角, その 稼動角の長さを PR 時間, ピンチローラーが作動開 始するタイミングを PS 角, 作動終了するタイミン グを PE 角とそれぞれ表記する. PDC 装置で送り出 される系の速度は, 駆動ローラーの直径 $(106 \mathrm{~mm})$ から計算して求め, 以後 PDC 周速度と表記する. 特に断らない限り, DR 回転数は6,900 rpm, PS 角 は $106^{\circ}, \mathrm{PE}$ 角は $170^{\circ}$ そて PR 時間は $64^{\circ}$ である.

\section{3 よこ糸運動の測定}

本研究では, よこ糸張力, よこ糸先端位置および

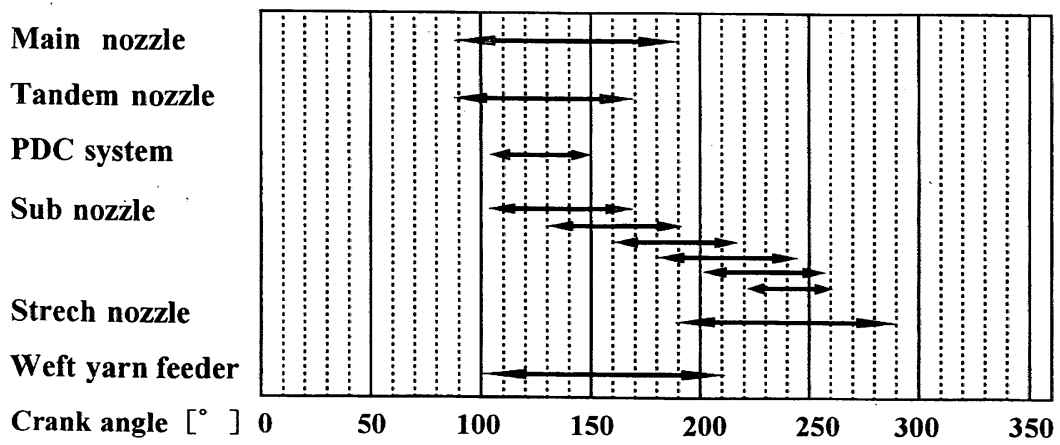

Fig. 1 Working conditions of various nozzles in AJL 
よこ糸速度からよこ糸運動特性を評価する.

よこ系張力は, 応答周波数 $1 \mathrm{kHz}$ の 3 ピン式張力 計（インテック㑣：IT-HY) を用いてサンプリング タイム $100 \mu \mathrm{s}$ で測定した.この張力測定位置を図 2 中の i で示す. PDC 装置装着の場合はメインノズル と PDC 装置の間 (case 1), PDC 装置を装着しない 場合は, メインノズルとタンデムノズルの間 (case

2) でそれぞれ張力測定を行った.

よこ系速度の測定には多くの方法がある ${ }^{5 \sim 8)}$. 本 実験では, 高速カメラ画像処理システム（コダック 製：EktaPro）を使用して, よこ糸先端位置を0.5 $\mathrm{ms}$ 間隔（2000コマ/s）で測定し，その結果からよ こ糸先端速度を算出した. 図 3 は, よこ糸飛走画像 の代表例であり, 図中の(1)，(2)および(3)は，それぞ れ0.5msごとに撮影した映像である. よこ糸の先端 は, 時間の経過に伴って, 図中右方向に進んでいる ことが分かる．おさにはメインノズルからの系先端 位置が判断できるようにマーカーを付け，これを参 考にしてよこ糸の先端位置 (織機メインノズル先端 からの距離）を求めた. よこ系飛走画像の解析は,

(1)

\section{Inserting direction of weft yarn

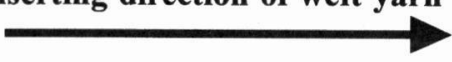

Marker on the Reed

(2)

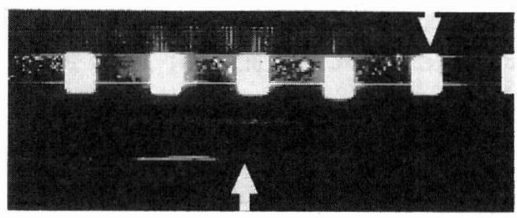

Yarn Tip

(3)

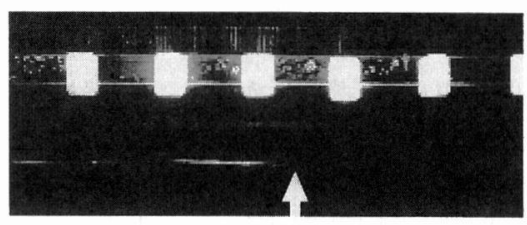

Yarn Tip

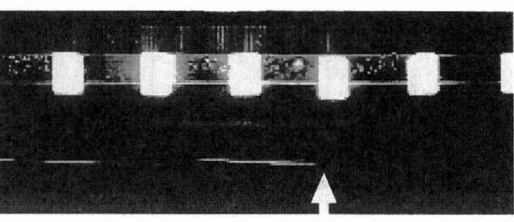

Yarn Tip

Fig. 3 High speed photographs of the tip position of weft yarn
倍率が約1.27倍, 画像分解能が1.2mm ( $10.2 \mathrm{~mm})$ の設定で行った. また, 織機のクランク角 100 度に同 期して発光するストロボ信号を高速カメラ画像に取 り込み,この信号タイミングを基準に各画像のクラ ンク角度を求めた。

よこ糸先端糸速度 (以後単によこ糸速度と表記す る）は, 上記した飛走画像より求めた先端位置と画 像撮影時間より計算して求めた。 ただし, 測定值の ばらつきを低減するために測定回数を多くし，よこ 系速度は移動平均 $\left.{ }^{9}\right)$ (標本数；10）を用いて表示し た.

\section{4 試 料}

たて糸は, 市販のポリエステル原着系（黒色： 16.7tex/48f） に撚系（S700t/m） 加工を施した糸 （実測瀻度17.3tex）を使用した。 よこ糸飛走状態の 高速カメラ撮影を容易にするために, $1 \mathrm{~cm}$ ごとにた て糸のない (空羽) 糸配列にし，たて糸が存在する 部分のたて糸密度は19本 $/ \mathrm{cm}$ とした. よこ糸は市 販のポリエステルウーリー系 (33tex/72f : 実測繊 度33.5tex）を使用した。

\section{3. よこ糸飛走状態}

通常のジェットルームにおけるよこ糸飛走状態 は, 自由飛走と拘束飛走に分類されている ${ }^{10)}$.この 分類に従うと, 自由飛走とは測長装置に眝留中のよ こ糸がガイドの摩擦や空気抵抗等の搬送抵抗力と水 や圧縮空気から付与される搬送力により決定する速 度で飛走する状態である. 他方, 拘束飛走は, よこ 糸を機械的機構で積極的に送り出す給糸状態の場合 に出現し，よこ系に搬送力が働いているにあかかわ らず，よこ糸が機械的に送り出される速度と同じ速 度で飛走する状態である. AJLの場合, フィーダー 型测長装置使用時のよこ糸は自由飛走状態であるの に対し，エアプール方式測長装置使用時のよこ系は 最初自由飛走状態であり, その後拘束飛走状態とな $3^{11)}$.

本報で扱う PDC 装置は, 図 2 で示すようにフィ 一ダー方式測長装置を使用するためよこ糸は自由飛 走である。 また, PDC 装置の稼動中は PDC 装置が 機械的によこ系を送り出すため拘束飛走が存在する 可能性があると考えられる. さらに詳細に PDC 稼 働状態を検討すると, 前報 ${ }^{4}$ で示したよこ系飛走状 態の高速度カメラ画像やよこ糸張力波形より, PDC 装置使用時の自由飛走状態は装置を使用しない場合 
と比較して搬送抵抗力が低減された飛走状態と考え られる. 以後, PDC 装置稼動により生じる搬送抵抗 力の低い自由飛走状態を低張力飛走と表記する。こ れら 3 種類の飛走状態を考慮して，PDC 装置使用 時のよこ糸飛走状態を検討する.

\section{4. 結果亡考察}

\section{1 よこ糸飛走状態の解析}

\section{1）よこ糸先端位置およびよこ糸速度}

図 4 は，よこ糸先端位置を織機クランク角度に対 してプロットした結果を示す，ただし，(1)および(2) 図は，それぞれ PDC 装置を使用した場合とタンデ ムノズルを使用した場合である．また，これらの図 中の曲線（以後 TP 曲線と表記する）は，測定点を 最小二乗法を使用して多項式近似した結果であり， これらの曲線は測定結果を良く代表していることが わかる．PDC 装置使用時の TP 曲線とタンデムノズ ル使用時のそれとの相違を検討するため，(3)図にこ れらの近似曲線のみを表示する. (3)図より, PDC 装 置使用時の TP 曲線とタンデムノズル使用時のそれ には全体的に明確な相違が見られない。しかし，詳 細に検討すると，曲線の中央領域とよこ入れ終了領
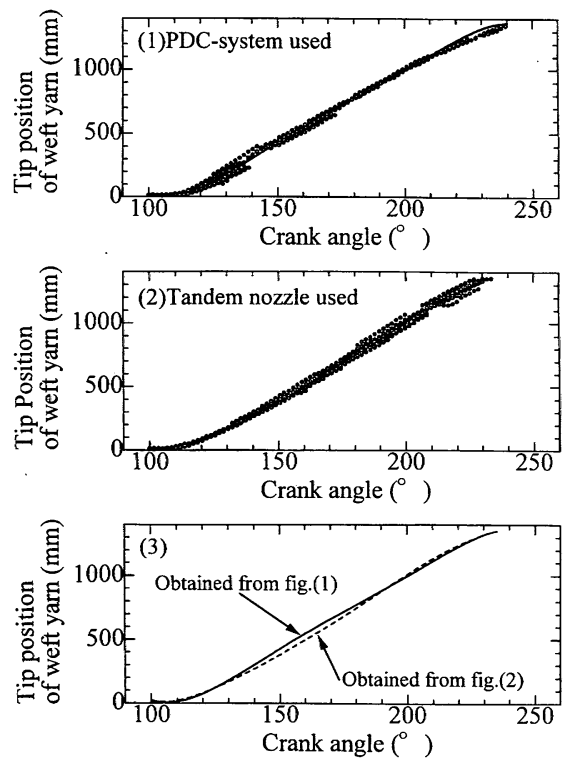

Fig. 4 Relation between tip position of weft yarn and crank angle when PDC-system is used : (1), Tandem nozzle is used : (2), and approximate curves of these relations : (3)
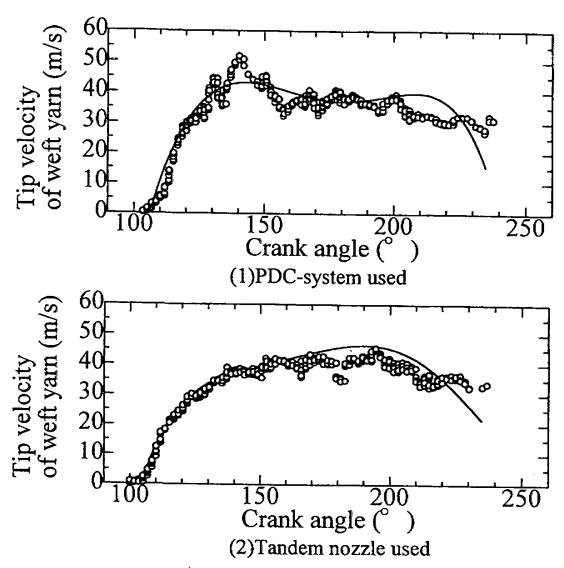

Open circle : experimental data

Soid line : calculated curves obtained from Fig.4

Fig. 5 Relation between tip velocity of weft yarn and crank angle when PDC-system is used : (1), Tandem nozzle is used : (2)

域に違いが見られ，PDC 装置使用時の方が，よこ入 れ途中は高速度でよこ入れが行われ，最終的によこ 入れ終了付近では減速していることがわかる。

図 5 は，よこ系速度を織機クランク角度に対して プロットした結果を示し，(1)図は PDC 装置使用時 であり, (2)図は夕ンデムノズル使用時である. また, 図中の曲線は，図 4(3)に示した近似曲線を微分する ことにより得られた速度曲線（微分曲線）である。 $\mathrm{PDC}$ 装置使用時のよこ糸速度とタンデムノズル.使 用時のそれには, 図 4 の場合とは異なり明確な違い が見られる，すなわち，PDC 装置を使用した場合の よこ糸速度 (測定值) は，クランク角 $140^{\circ}$ でピーク を示し, その後はクランク角の増加に伴って若干振 動しながら減衰している。これに対し，タンデムノ ズルを使用した場合は，よこ糸速度の急激なピーク は観察されない. タンデムノズル使用時は, 微分曲 線とよこ系速度の測定值は，よこ入れ終了時近傍を 除き良く一致している. 他方, PDC 装置使用の場 合, クランク角 $140^{\circ}$ 前後とよこ入れ終了近傍で微分 曲線と測定値間に大きなずれが観測される，一般的 にいって, 微分操作は急激な変化をとらえるのに有 効であり, PDC 装置の稼動により糸速度が急激に 変化することが期待される場合は TP 曲線と比較し てよこ糸速度の方がよこ糸の飛走状態を明確に表現 できる．よこ糸速度については後に詳細に議論す る.

2）よこ糸張力 

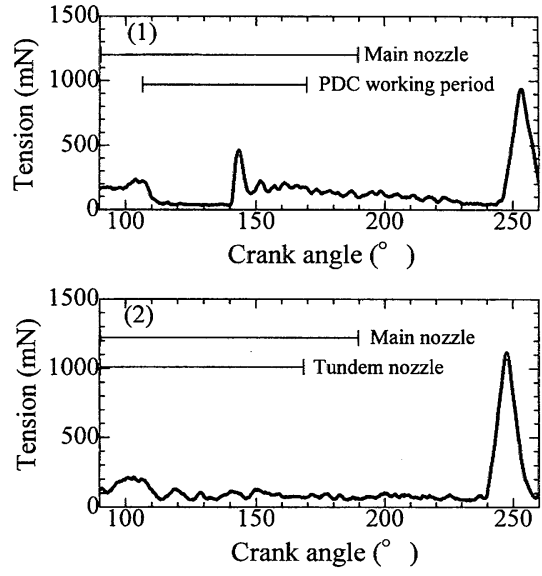

Fig. 6 Variation of yarn tension during weft insertion when PDC-system is used : (1), and Tandem nozzle is used : (2), and the working periods of the nozzles are shown.

図 6 は, よこ入れ期間の張力波形を示し，(1)は PDC 使用時, (2)はタンデムノズル使用時である.こ の図より, PDC 装置使用時とタンデムノズル使用 時ではよこ糸張力波形に明確な違いが観測される. PDC 装置の場合, よこ入れ開始時 $\left(100^{\circ}\right)$ に幅広く 低い張力ピークが出現し, 次に PS 角 $\left(106^{\circ}\right)$ で急激

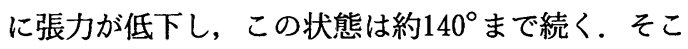
で再び張力ピークが発生し, ピーク終了後, 張力は よこ入れ終了直前 $\left(250^{\circ}\right.$ 近傍のピークは除く)まで, 低レベルの状態で若干隇少しながらも保持されてい る. 他方, タンデムノズルの場合は, PDC 装置使用 時と同様によこ入れ開始時にピーク張力が発生する が，それ以降はほぼ一定張力を示す。このように, $\mathrm{PDC}$ 装置使用時のよこ糸張力波形は, タンデムノ ズル使用の場合と異なり，2つのピークが存在し， ほぼ一定張力を示す領域がこれらピークの前後に 3 つあることがわかる.

\section{3）よこ糸飛走状態に対する議論}

よこ糸先端速度およびょこ糸張力波形から，PDC 使用時のよこ糸飛走状態は, タンデムノズル使用時 のそれと異なることは明らかである，そこで，実験 条件として任意に設定した PDC 稼動条件と観測さ れたよこ糸張力波形を足掛かりに，PDC 装置使用 時のよこ系飛走状態を分類し, 各領域での系速度と 飛走状態を考察する．この際，飛走領域を図 7 に示 すような 4 領域に分類することは, 合理的であろ う.

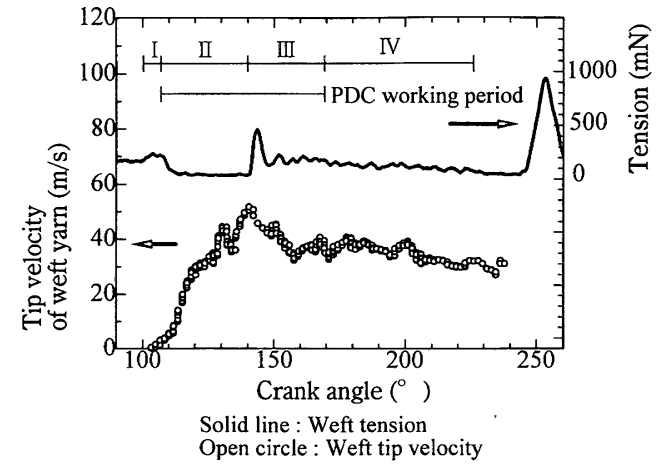

Fig. 7 Determination of regions which are seen during weft insertion when PDC-system is operated

領域 I（100 106 ${ }^{\circ} ）$ は PDC 装置未稼動期間であ り,この領域のよこ系状態は低速の自由飛走状態に あると思われる.

領域 II $\left(106 \sim 140^{\circ}\right)$ はよこ糸速度が最大值を示す までの領域であり，PDC 装置稼動期間である．よこ 系張力波形では非常に低い張力状態が観測されるこ とより，よこ糸は低張力飛走状態である．この低張 力飛走時のよこ系速度はタンデムノズル使用時のそ れより大きく，よこ系が急激に加速されているのが わかる.さらに, よこ系速度の最大值 $(V \max )$ は50 $\mathrm{m} / \mathrm{s}$ 以上の值が観測され (図 5 参照), タンデムノ ズル使用時（約 $40 \mathrm{~m} / \mathrm{s}$ ) より明らかに大きい。この 高い速度が観測された理由は，タンデムノズル使用 の場合，糸のバルーニング等による抵抗力がよこ糸 に働くのに対して，これらの抵抗力が働かず，圧縮 空気の搬送力がよこ糸加速に有効に利用できるため と考えられる．また， PDC 使用時の Vmax は PDC 周速度 $(38.3 \mathrm{~m} / \mathrm{s})$ と比べて明らかに大きく，この 相違について以下に考察する.PDC 装置稼動に伴 いよこ糸は PDC 周速度で送り出される. しかし， PS 角付近でのよこ糸速は $10 \mathrm{~m} / \mathrm{s}$ 以下であり， PDC 周速度より遅い (図 5 参照). そのため PDC 装置通 過直後のよこ系には緩みが生じ，この緩みが解消さ れるまで圧縮空気による加速が可能になり，PDC 周速度より大きなよこ糸速度が観測されたと考えら れる（よこ糸のたるみについては前報で明らかにし ている).

領域 III $\left(140 \sim 170^{\circ}\right)$ も PDC 装置稼動期間であ る.この領域のよこ糸速度は近似曲線からはずれ， アンダーシュウ気味に減速している. よこ糸速度の 減速が始まる位置（クランク角）とよこ糸張力波形 
で観測されるピーク張力位置 (図 6 参照) が一致す ることより, ピーク張力を示す原因は, よこ糸が急 激に減速しているためである. 減速後のよこ糸速度 が PDC 周速度に等しい約 $40 \mathrm{~m} / \mathrm{s}$ の定速状態を示す ことより,この領域のよこ系は PDC 周速度で決ま る拘束飛走状態にあることがわかる. 前述したよこ 糸速度が近似曲線からアンダーシュウ気味に減速す る理由は, 圧縮空気による搬送力に比較して, よこ 系の張力が大きくなり, 糸先端に進行方向と逆の力 が作用し，系先端が減速されるためと考えられる.

また, タンデムノズル使用の場合, 測定されたよこ 糸速度とその近似曲線とはよく一致しており, 急激 な状態変化がなく, 比較的なめらかなよこ入れが実 現されていることがわかる.

領域IV（170〜よこ入れ終了）では PDC 装置の 稼動が終了しており，この領域でのよこ糸は自由飛 走である. しかし, 今回の実験では, PDC 周速度と その後の自由飛走時の系速度がほぼ等しいために, 張力波形およびよこ糸速度には PE 角前後での状態 変化を明確に示す現象が観察されず, 拘束飛走から 自由飛走へ連続的に移行していると思われる。 ま た, PDC 装置使用時のよこ糸速度 (測定值) は, 夕 ンデムノズル使用時に比較して, 早いクランク角か ら減少しているのがわかる (図 5 参照).PDC 装置 使用の場合, 次の 2 つのよこ糸減速機構が考えられ る. 第 1 の減速は ( $170^{\circ}$ 以降), PDC 装置の稼動終 了に伴いよこ糸にバルーニングなどの抵抗力が働く ために生じ，第 2 の減速は織機メインノズルの稼動 終了 $\left(190^{\circ}\right)$ に伴いよこ糸の搬送力が減少したため に生じる. 以上より，よこ入れ終了時のピーク張力 が PDC 装置使用時の方がタンデムノズル使用時よ り小さくなる原因は, PDC 装置の場合この $2 つ の$ 減速機構のためによこ入れ終了時の糸速度がタンデ ムノズル使用時より低くなるためであると考えられ る (図6 参照).

以上より, よこ糸の張力波形とよこ系先端速度の 計測より PDC 装置使用時のよこ糸飛走状態が明ら かになった。

\subsection{PDC 稼動条件がよこ糸飛走状態に及ぼ す効果}

\section{1 ）駆動ローラー回転数の影響}

図 8 は, DR 回転数と低張力飛走期間 (Ptime II) およびよこ糸最高速度 (Vmax) の関係を示す. DR 回転数の増加に伴い, Ptime II は増加し, Vmax は

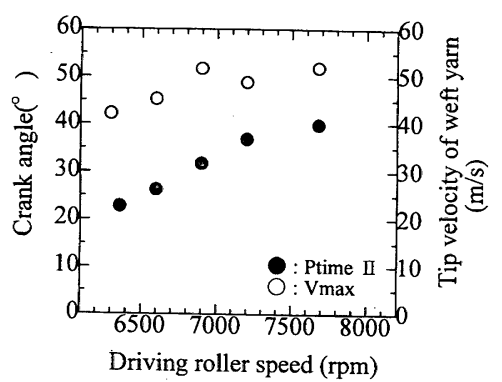

Fig. 8 Effects of driving roller speed on Ptime II and $\mathrm{Vmax}$

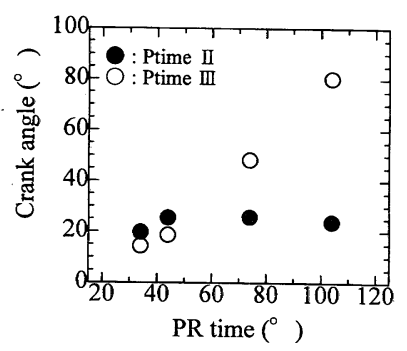

Fig. 9 Effects of working period (PR time) of PDC-system on Ptime II and Ptime III

増加後一定值に漸近しているように見えるＶVmax が一定值に漸近する理由は, Vmax はノズルの圧縮 空気圧に依存するためと考えられる，また，Vmax が一定值に漸近する領域では, Ptime II 増加はよ こ糸が Vmax で飛走する時間の増加を意味し，こ のことが前報で示した DR 回転数の増加に伴い, よ こ入れ時間が短縮される理由である.このように, よこ糸飛走状態を DR 回転数を変化させることで容 易に制御でき, 製織可能なよこ糸種類が増えること 之製織効率向上の可能性を示唆している.

2) ピンチローラー稼動タイミングの影響

PDC 装置稼動タイミングの PR 時間（PS 角を $106^{\circ}$ に固定し， PE 角を変化させて決める）がよこ 糸飛走状態に与える影響を検討し，その結果を図 9 に示す. PR 時間の増加に伴い, 拘束飛走期間 (Ptime III) は増加し, 他方, よこ糸の低張力飛走期 間（Ptime II） は若干の増加後一定値を示すことが わかる. このことは, PR 時間を適切に設定するこ とにより，よこ系の拘束飛走期間を自由に制御でき ることを意味する。 また Ptime II が PR 時間に依存 しない理由は，低張力飛走状態の説明から明らかで ある.

以上の結果より, 圧縮空気圧力および各種ノズル 
タイミングを変化させなくても PDC タイミングの 設定により，適正なよこ糸速度曲線を簡単に設計で き，製織効率を上げることが可能になることがわか る.

\section{5. 結 言}

PDC 装置を使用する場合, 特有のよこ系の張力 変動が観察され，この原因をよこ糸先端速度の計測 より検討した。 その結果, PDC 装置を使用した場 合, 従来の自由飛走より抵抗力の小さい自由飛走 （低張力飛走）が存在し, よこ糸飛走状態は自由飛走 ・拘束飛走・低張力飛走で構成されることが明らか になった，さらに，PDC装置稼動条件の設定によ り, よこ系飛走状態, 特に低張力飛走状態之拘束飛 走状態の領域を大きく変化させられることが明らか になった．この事は, 圧縮空気圧力および各種ノズ ルタイミングを変化させなくても, PDC 装置の稼 動条件の適切な設定により，よこ糸飛走状態を自由 に制御できることを意味し，製織効率の向上および 製織可能なよこ糸種類の増加が期待される.

なお，本研究の一部は日本繊維機械学会北陸支部 研究発表会（平成10年12月11日，福井）において発
表した. また，本研究を進めるに際しご協力いただ いた福井県工業技術センターの諸氏に感謝する.

\section{参考文献}

1) Weaving Machine Research Commit ; "Jet Loom Weaving”, P9, J. Test. Mach. Soc. Japan (1989)

2) J. J. Vincent, Y. Armon, N. Hodgkinson and G. Willis, J. Text. Inst., p. 543 (1962)

3) I. Hasegawa and T. Kidokoro (Micron Co.) ; Publication of Unexamined Japanese Patent Application 09095839

4) A. Masuda, Y. Sogi and N. Ogata ; J. Test. Mach. Soc. Japan (Japanese Ed), 52, T9 (1999)

5) M. Uno, T. Ishida, Y. Kimura and T. Shinkai ; J. Test. Mach. Soc. Japan (Japanese Ed), 14, 141 (1961)

6) G.Hoth, M. von Thenen ; Textile Praxis International, July, p. 650 (1993)

7) K. Yoshida, F. Suzuki, S.Kawabata and J. Hasegawa ; J. Test. Mach. Soc. Japan (Japanese Ed), 44, T32 (1991)

8) Y. Kisanuki and K. Yoshida ; J. Test. Mach. Soc. Japan (Japanese Ed), 50, T16 (1997)

9) A. Horikawa, "Randamu Hendou no Kaiseki ", p. 22, Kyouritusyuppan Co. (1968)

10) Weaving Machine Research Commit; "Jet Loom Weaving” , P188, J. Test. Mach. Soc. Japan (1989)

11) Weaving Machine Research Commit ; "Jet Loom Handbook", P62, J. Test. Mach. Soc. Japan (1982) 